\title{
1. Introduction: energy and the geographical traditions
}

\author{
Barry D. Solomon and Kirby E. Calvert
}

Interest in energy has spiked among geographers recently, though historically speaking such attention has been highly cyclical based on oil prices, accidents and energy crises (Solomon et al., 1989; Solomon and Pasqualetti, 2004; Thoyre and Harrison, 2016). Some of our readers will be old enough to have seen this before. The energy crises of the 1970s spurred many geographers to become energy experts almost overnight, many of whom likely ignored a call made by Chapman (1961) over a decade earlier. Several entry-level texts and articles were written, with a primary focus on the economic geography of energy (e.g. George, 1950; Manners, 1964; Linton, 1965; Luten, 1971). The first post-World War II monograph on energy geography was written by George (1950), but received little notice outside of France. Perhaps unfortunately, no single agreed upon synoptic definition of the subfield and its methods emerged.

Although important conceptual, methodological and pedagogical foundations of energy geography were laid during the 1960s and 1970s (Pryde, 1985), interest with energy studies was reactionary and short-lived. Research greatly receded in the 1980s as new oil sources were found, geopolitical relations were restored and oil prices leveled off (Thoyre and Harrison, 2016). There is reason to believe that the recent interest is genuine and driven by more profound scholarly interests. Indeed, energy is becoming a focus for teaching and research programs across the discipline, not just one-off courses and projects. We use the term geographies in the title of this Handbook to reflect the fact that the study of energy has become a focal point for a range of perspectives and methods from across the discipline (Calvert, 2016).

The reasons to study energy are probably obvious to you. Many of the grand and persistent challenges of our times can be traced directly to the production, distribution and use of energy. Whether you are interested in staving off unstable and dangerous climate change, fostering (equitable) wellbeing across society or achieving sustainability in your everyday life, you are forced to confront energy. These noble pursuits aside, curiositydriven quests for knowledge also come to center on energy eventually. The desire for greater energy supplies features prominently in the story of the evolution of our species, including our relationship with the non-human world (Cook, 1976), how social norms and built environments are established (Nye, 1999) and how we all get along (or do not) with each other (Montgomery, 2010). And energy, along with matter, is a fundamental concept in any basic explanation of physical phenomena or technological design.

But why study energy from a spatial perspective? What value do geographers and a geographical perspective add to the theories and practices put forward by physicists, engineers, geologists, economists, sociologists and others? In the next section we will try to answer this question in order to situate the study of energy within (our combined interpretation of) broader disciplinary trends. We follow this discussion, in the third section, 


\section{Handbook on the geographies of energy}

by describing the Handbook's organization. But before proceeding with a discussion of what this Handbook is and does, it is important to underscore what it is not and does not do. First, this Handbook is not focused on energy as a physical entity per se. Energy is certainly a central concept for physical geographers, and anyone interested in seriously studying energy needs a basic understanding of the principles of energy transfer through physical and technological systems. These important studies aside, this Handbook is interested in energy as a social relation; that is, in the study of social and socio-ecological processes that shape, and are shaped by, the production, distribution and use of energy. Second, due to space limitations the Handbook does not capture the full constellation of energy geographies. Even after limiting the scope as just described, we recognize crucial missing pieces from key analytical domains such as cartography (Howell and Baylis, 2014); rural studies (Frantál and Martinát, 2013); the new economic geography (e.g. Mohan and Power, 2009); energy balance climatology (e.g. Dozier and Outcalt, 1979); climate change (e.g. Harvey, 1988); critical physical geography (Lave and Lutz, 2014); and the use of spatial analysis and other quantitative methods (e.g. Haynes et al., 1983; Upchurch et al., 2009). These limitations notwithstanding, the goal of this Handbook is to provide emerging scholars and professionals with a sense of how one might contribute to, and benefit from, this fertile and fast-growing academic borderland of energy geographies.

\section{ENERGY AND THE GEOGRAPHICAL TRADITIONS}

For better or worse, the discipline of (Anglo-American) geography has lacked a central dogma, resting instead on the laurels of interdisciplinary departments and perspectives. Bound only by the study of Earth's complexity from a broadly defined 'spatial dimension' - that is, spatial patterns, connectivity and flows, object-context relations (and the fallacy of this binary) - geographers are a diverse bunch. Our work can be identified within a methodological and conceptual matrix that includes the subfields of human geography, physical geography, human-environment (nature-society) geography and cartography/GIScience (Pattison, 1964; Robinson, 1974; Zimmerer, 2010).

Geographical perspectives within geography's core traditions have already proven useful to energy studies in several arenas. Concepts in human geography, for example, are critical to understanding the effects of a wholesale transition to renewable energy on prevailing social and social-ecological relationships (Jiusto, 2009; Bridge et al., 2013). Many of these concepts have recently been brought into dialogue with theories of sociotechnical transitions in order to identify the context-dependent and cross-scalar relationships which enable and disable transition processes in particular places (Hansen and Coenen, 2015). Fast (2013) explains how spatial and geographic reasoning improves our understanding of community and individual acceptance of renewable energy resource development, and Delgado (2016) explains how concepts in geography's critical approach to political economy elucidate how oil markets function and expand into new regions. Although human geographers have been most active in energy studies, contributions have emerged from other facets of the discipline. Pulselli et al. (2008), for example, demonstrate the value of a geographical perspective to better understand the flow of energy through coupled social-ecological systems. And from geography's cartography/GIScience tradition, Horner et al. (2011) and Calvert et al. (2013) extol the virtues of geographic 
information and spatial decision-support in improving the efficacy of energy policy and planning decisions.

Increasingly, geographers are identifying and binding their work topically, rather than (or in addition to) these subfield designations. Topical studies represent academic borderlands; that is, areas of study at which otherwise disparate or disjointed systems of geographical thought and practice from the core subfields of geography can converge and engage over the study of a common issue or region. Academic borderlands, much like the borderlands between two nations or two biomes, often prove to be the richest and most diverse areas of study (Zimmerer, 2010). To study the geographies of energy is to contribute to an academic borderland. The propensity among geographers to embrace interdisciplinarity through the exploration of academic borderlands has proven an asset to energy studies writ large. Exemplary here are recent efforts to combine a systems perspective with a critical perspective in order to better understand the social and environmental impacts of (renewable) energy production (see, e.g., Baka and Bailis, 2014; Birch and Calvert, 2015). Furthermore, geographers have been at the forefront of innovative interdisciplinary conceptual frameworks, which are not only improving our understanding of energy, but also providing new concepts and methods by which to advance our understanding of Earth's complexity. Examples of this include critical physical geography (Lave and Lutz, 2014) and political-industrial ecology (see Baka, Chapter 34 in this volume).

\section{ORGANIZATION OF THE BOOK}

The Handbook attempts to capture the geographical study of energy in all of its forms and is divided into six major parts. We begin with a crucial distinction across the first two parts of this Handbook. Part I has seven chapters on Fuels. Fuels are stocks, and are potential energy stored in physical form. Fuels can be extracted, processed, converted, concentrated and stored for later use. Examples include biomass, the fossil fuels (coal, oil and gas) and fissile nuclear fuel. Energies, in contrast, are the focus of Part II and represent kinetic flows of the capacity to do work, they are generally renewable and difficult to store.

Traditional biomass energy, that is, firewood, dung and eventually charcoal, were humanity's first major fuel sources (Smil, 1994). In Chapter 2, Matthew Taylor discusses the role of biomass energy for cooking in developing countries, and the slow transition to cleaner burning fuels. This includes ongoing debates over whether there is a fuelwood 'crisis', the role of gender, impacts of combustion on human health, sustainability, and if the use of wood fuel is contributing to deforestation. During the Industrial Revolution, biomass energy was not up to the task so the UK, Europe and the USA switched to coal, which today is the most abundant fossil fuel. In Chapter 3, Max Woodworth situates the continuing importance of coal within the social geographies of its exploration, production, combustion and its mitigation. Yet despite coal's widespread distribution and high energy density, its future is cloudy. Given its high level of pollution and carbon emissions, only those countries struggling to ensure access to relatively cheap energy for a fastgrowing population remain committed to high coal usage, most notably populous China and India. The number one global energy source, however, is oil, the topic addressed by Philippe Le Billon and Gavin Bridge in Chapter 4. Le Billon and Bridge frame their 
discussion in terms of the Anthropocene, the increasingly accepted term for the current geological age wherein human influence has been the dominant force on climate and the environment. They argue that in this context the (geo)politics of oil is increasingly about its environmental and social signature, and highlight some of geography's distinctive contributions towards thinking about and understanding oil's future. In addition to coal's lingering dominance in the energy mix, natural gas has also established an ascendant position, especially in the USA and Russia, and in the electric power sector. In Chapter 5, Julia Haggerty considers the supply chain of gas production, transport and use worldwide, but highlights the role of high-volume hydraulic fracturing, or 'fracking', and the use of shale rock in gas's growing fortunes. While fracking is controversial, it has largely been accepted as necessary for gas (and oil) production in Texas, Oklahoma, Pennsylvania and other high production areas.

Beyond fossil fuels, the other major fuel that was once heralded as the answer to energy shortages worldwide is uranium, used for nuclear power generation, primarily U-235. Phil Johnstone considers the geographical dimensions of nuclear power and radioactive wastes in Chapter 6. While only 31 countries generate nuclear power, the topic has long been a focus of geographers. A substantial amount of work on nuclear has been conducted, ranging from power plant siting to risk assessment and radioactive waste management. Given its controversy, owing to disastrous accidents, high costs, unresolved waste disposal and potential proliferation of nuclear weapons, geographers will have ample opportunity to remain engaged in this research area. Finally, advanced biofuels among other alternatives have emerged over the last four decades as important supplemental fuels in the transportation sector. Kirby Calvert and his colleagues address these options in Chapters 7 and 8. First, Chapter 7 reviews techno-economic perspectives on advanced biorefining, which required feedstocks from both the forestry and agricultural sectors. Focusing on North America, the chapter uses the environmental economic geography (EEG) framework to shed light on emerging landscapes for ethanol and biodiesel production. Chapter 8 in turn goes beyond biofuels and considers compressed natural gas, hydrogen fuel cells and several electric vehicle configurations. The authors highlight the strategic roles that geographers can play in working through the many alternative fuel pathways.

Five energy chapters comprise Part II of the Handbook. In Chapter 9, Mary FinleyBrook discusses hydroelectric power generation. Hydropower is the most used renewable energy source for power production. Scale matters, and hydroelectric projects vary greatly in size. There is debate over whether hydroelectric development should continue or is viable under climate change scenarios, while multi-scale opposition movements frequently attempt to deter large-scale dams in areas of cultural and biological diversity. Martin Pasqualetti and Barry Solomon review wind power and geography in Chapter 10. With wind farms now in over 100 countries around the world, wind remains one of the fastest growing energy sources. Ironically, much of the research has focused on public opposition to wind farms, which goes beyond the common 'not in my backyard' explanation. In Chapter 11, Dustin Mulvaney addresses solar energy with a focus on the photovoltaic industry. Along with wind power, solar energy production and use has been growing dramatically. His chapter considers several photovoltaic technologies, mostly for end users, as well as centralized, concentrated solar power technology. After a review of the global industrial structure, Mulvaney turns to solar energy transitions and its enabling policies. Edward Louie and Barry Solomon consider geothermal energy in Chapter 12. While not 
strictly renewable, geothermal energy can be used for direct heating and heat pumps as well as for electricity generation. Though less researched by geographers than wind power, geothermal raises many geographic issues: land use compatibility and planning, ecological and environmental impacts, social barriers, sustainability and more. Contrasting attitudes towards geothermal development are shown by case studies of Iceland versus national parks in the USA. In Chapter 13, Peter Connor and Helen Smith review multiple marine renewable energy technologies: offshore wind, waves, tidal streams/ocean currents and tidal barrage/range. Thus far only offshore wind has seen significant commercial application, currently over $12 \mathrm{GW}$, with most projects off of the UK and Germany.

Part III contains four chapters addressing energy consumption, sectors and end uses. These include buildings, industry, transportation and the electric power grid. Jenny Palm and Kajsa Ellegård begin the part in Chapter 14 by offering insights on residential energy consumption in Sweden from a time-geographic perspective. They examine household members' time diaries to detail what energy-related activities are used and at what time of day or night. Visualization techniques are used to track the relationship between activities, appliance use and electricity consumption. In Chapter 15, Kevin Lo reviews energy efficiency programs in China, which is also the world's largest emitter of greenhouse gases. His chapter considers multiple energy saving programs in industry, buildings, transportation and local government sectors. The evidence supports the idea that energy efficiency programs in China are flexible and do not always rely on top-down governance. Future programs are becoming more market oriented, which will be important as China tries to meet energy consumption caps. In Chapter 16, Christophe Enaux, Phillipe Gerber and Helene Haniotou explore energy use in the transportation sector, considering alternative modes and the latest developments in mobility. This includes key determinants of car dependency as well as policy prescriptions for energy transitions. In Chapter 17, Steve McCauley and Jennie Stephens turn to the electric power grid, with emphasis on the social geographies associated with increasingly decentralized systems. This is in sharp contrast to still prevalent centralized regulatory regimes. While there is a changing landscape of electric utilities and their grids, they are emerging rather slowly.

In the spirit of traditional regional approaches to energy studies, and in order to elucidate the varied ways in which energy flows are socially constructed around the world, we include a part on regional energy transitions. This is the longest section of the Handbook; Part IV has 11 chapters, and is entitled 'Changing landscapes of energy production, distribution and use'. The chapters in this part build on energy geography's oldest tradition, which is to describe energy-related changes occurring on the Earth's surface (Linton, 1965). The chapters in Part IV are not merely descriptive, however, as they move beyond traditional regional and economic geography approaches to energy. Dan van der Horst begins, in Chapter 18, by envisioning energy landscapes of less than 2 degrees Celsius global warming above pre-industrial levels, the goal of the 2015 Paris Agreement under the United Nations Framework Convention on Climate Change. This new research topic sets the stage well for Part IV, as energy analysts worldwide need to think about such changes in great detail. The next eight chapters address major regional or national case studies in energy geography: Europe, by Harriet Thomson and Stefan Bouzarovski; Russia, by Jessica Graybill; North America, by Warren Mabee and colleagues; Brazil, by Mauricio Tolmasquim and Angela Livino; sub-Saharan Africa, by Robert Stock; Nigeria, by Michael Watts; and India, by Deepti Chatti. These chapters cover the world's most 
populous regions and land areas, with a few exceptions (e.g. Australia, Mexico, Indonesia, Pakistan, Bangladesh and China, though China is covered in part in other chapters). In Chapter 26, Sven Stremke and Paolo Picchi discuss how to use geographic information systems and participatory mapping (PM) to explore low-carbon futures. The authors provide a framework for co-designing sustainable energy landscapes, with special attention to PM and the role of ecosystem services. In Chapter 27, Ping Huang and Vanesa Castán Broto consider energy landscape transitions at the urban scale. They focus on the context of change, and propose a socio-ecological framework to understand these contexts. Two Chinese cities are used as case studies. Finally, Chapter 28 by Helmut Haberl and his colleagues close Part IV, and use a socio-economic metabolism perspective to envision global energy transitions. This is a long-term quest, and the authors show how energy flow analysis can provide important insights on past agrarian-industrial transitions at large-scale regional levels.

Part V has four chapters addressing the nexus between energy and other policy issues. In Chapter 29, Hayley Leck and her colleagues consider the close connections between energy, water and food - the 'resource trilemma'. They discuss recent initiatives framed around this discourse, which can be either politicizing or depoliticizing. Attention is also paid to challenges of governance, operationalization and fulfilling the type of disciplinary boundary crossing advocated by the nexus agenda. Energy poverty and vulnerability are addressed in Chapter 30 by Neil Simcock and Saska Petrova. Energy poverty is the inability to attain a socially and materially necessitated level of basic domestic energy services for space heating, lighting, refrigeration and cooking. The authors argue that domestic energy deprivation in its different guises and forms is tied to the ineffective operation of the socio-technical pathways that allow for the fulfillment of household energy needs. In Chapter 31, Karen Bickerstaff considers a related topic, the geographies of energy justice. Taking UK energy policy as a starting point, she explores policy surrounding different types of energy systems through the lens of environmental justice theory - specifically notions of distributional and procedural justice - and makes explicit links across systems of energy production and consumption. In Chapter 32, Arielle Hesse turns to the intersection between energy and human health. Drawing on her research on occupational health in the US shale fuels industry, the chapter raises questions about the role of knowledge in how the state governs energy workplaces and energy workers' health and considers the underlying assumptions and techniques of the state.

Part VI 'Looking forward', the Handbook's last part, explores creative conceptual and methodological frameworks that are sharpening the leading edge of energy geographies with five final chapters. In Chapter 33, Karl Zimmerer reviews the perspectives of both political ecology and social ecology towards energy research. The combined approaches of these perspectives are used to examine the geographies of energy and to synthesize the state-of-the-art contributions. Jennifer Baka, in Chapter 34, also considers political ecology but positions it in a framework with industrial ecology. Her chapter provides a political-industrial ecology analysis of jatropha biofuels promotion in South India, which challenges the 'pro-poor', 'pro-environment' and 'wasteland development' claims associated with jatropha in novel ways. In Chapter 35, Conor Harrison and Jeff Popke review critical scholarship by geographers that has been applied to energy issues. This research is organized around energy production, movement and consumption. A political economy perspective is included, and the authors also review recent work in anthropology and soci- 
ology that seeks to 'energize' critical social theories more broadly. In Chapter 36, Nichole Dusyk discusses community energy, that is, energy projects that include community involvement in open and participatory processes with local and collective outcomes and benefits. The final chapter, by Bruce Mitchell and Paul Parker, proposes that geographers adopt and adapt perspectives being applied to other natural resources besides energy, and suggest how uncertainties and conflict can be overcome. After discussing distinctive characteristics of energy, the authors review multiple perspectives for improving the management of energy resources.

\section{CONCLUSIONS}

Geography's on-again, off-again relationship with energy studies seems to have stabilized. That geography has much to contribute to energy studies is now obvious, as evidenced by the work reviewed in this Handbook. Building on the 'Looking forward' section and following Huber (2015), we hope that the conversation among geographers studying energy will shift and the level of dialogue will be elevated. Just as energy is considered to be foundational in the co-constitution of the physical world, we might ask: In what ways does energy co-constitute the social and the socio-ecological world? This question forces us to move beyond thinking about energy as merely a subject for analysis, and to embed energy firmly within the conceptual and methodological traditions of geography.

\section{REFERENCES}

Baka, J. and R. Bailis (2014), 'Wasteland energy-scapes: a comparative energy flow analysis of India's biofuel and biomass economies', Ecological Economics, 108, 8-17.

Birch, K. and K. Calvert (2015), '(Re)thinking “drop-in” biofuels: on the political materialities of bioenergy', Science and Technology Studies, 28, 52-72.

Bridge, G., S. Bouzarovski, M. Bradshaw and N. Eyre (2013), 'Geographies of energy transition: space, place and the low-carbon economy', Energy Policy, 53, 331-40.

Calvert, K. (2016), 'From "energy geography" to "energy geographies": perspectives on a fertile academic borderland', Progress in Human Geography, 40, 105-25.

Calvert, K., J.M. Pearce and W.E. Mabee (2013), 'Toward renewable energy geo-information infrastructures: applications of GIScience and remote sensing that build institutional capacity', Renewable and Sustainable Energy Reviews, 18, 416-29.

Chapman, J.D. (1961), 'A geography of energy: an emerging field of study', The Canadian Geographer, 5, 10-15.

Cook, E.F. (1976), Man, Energy, Society, San Francisco, CA: Freeman and Co.

Delgado, E. (2016), 'Energy geographies: thinking critically about energy issues in the classroom', Journal of Geography in Higher Education, 40, 39-54.

Dozier, J. and S.I. Outcalt (1979), 'An approach toward energy balance simulation over rugged terrain', Geographical Analysis, 11, 65-85.

Fast, S. (2013), 'Social acceptance of renewable energy: trends, concepts, and geographies', Geography Compass, 7, 853-66.

Frantál, B. and S. Martinát (eds) (2013), New Rural Spaces: Toward Renewable Energies, Multifunctional Farming, and Sustainable Tourism, Brno, Czech Republic: Institute of Geonics, Academy of Sciences of the Czech Republic.

George, P. (1950), La Géographie de l'énergie, Paris: Librairie de Médicis.

Hansen, T. and L. Coenen (2015), 'The geography of sustainability transitions: review, synthesis and reflections on an emergent research field', Environmental Innovation and Societal Transitions, 17, 92-109.

Harvey, L.D.D. (1988), 'On the role of high latitude ice, snow, and vegetation feedback in the climatic responses to external forcing changes', Climatic Change, 13, 191-224. 


\section{Handbook on the geographies of energy}

Haynes, K.E., F.Y. Phillips and B.D. Solomon (1983), 'A coal industry distribution planning model under environmental constraints', Economic Geography, 59, 52-65.

Horner, M.W., T. Zhao and T.S. Chapin (2011), 'Toward an integrated GIScience and energy research agenda', Annals of the Association of American Geographers, 101, 764-74.

Howell, J.P. and D.L. Baylis (2014), 'Mapping energy: cartographies of energy into the twenty-first century', Geographical Review, 104, 209-28.

Huber, M. (2015), 'Theorizing energy geographies', Geography Compass, 9, 327-38.

Jiusto, S. (2009), 'Energy transformations and geographic research', in N. Castree, D. Demeritt, D. Liverman and B. Rhoads (eds), A Companion to Environmental Geography, Hoboken, NJ: Wiley-Blackwell, pp. 533-51.

Lave, R. and B. Lutz (2014), 'Hydraulic fracturing: a critical physical geography review', Geography Compass, $8,739-54$.

Linton, D.L. (1965), 'The geography of energy', Geography, 50, 197-228.

Luten, D.B. (1971), 'The economic geography of energy', Scientific American, 225 (3), 164-75.

Manners, G. (1964), The Geography of Energy, London: Hutchinson's University Library.

Mohan, G. and M. Power (2009), 'Africa, China and the "new" economic geography of development', Singapore Journal of Tropical Geography, 30, 24-8.

Montgomery, S.L. (2010), The Powers That Be: Global Power for the Twenty-first Century and Beyond, Chicago, IL: University of Chicago Press.

Nye, D.E. (1999), Consuming Power: A Social History of American Energies, Cambridge, MA: MIT Press.

Pattison, W.D. (1964), 'The four traditions of geography', Journal of Geography, 63, 211-16.

Pryde, P.R. (1985), 'Energy courses in American geography departments', Journal of Geography, 84, 154-7.

Pulselli, R.M., F.M. Pulselli and M. Rustici (2008), 'Emergy accounting of the Province of Siena: towards a thermodynamic geography for regional studies', Journal of Environmental Management, 86, 342-53.

Robinson, J.L. (1974), 'A new look at the four traditions of geography', Journal of Geography, 75, 520-30.

Smil, V. (1994), Energy in World History, Boulder, CO: Westview Press.

Solomon, B.D. and M.J. Pasqualetti (2004), 'History of energy in geographic thought', in C. Cleveland (ed.), Encyclopedia of Energy, Vol. 2, San Diego, CA: Elsevier, pp. 831-42.

Solomon, B.D., M.A. Brown and L.M. Freeman (1989), 'Energy geography', in G.L. Gaile and C.J. Wilmott (eds), Geography in America, Columbus, $\mathrm{OH}$ and Toronto: Merrill Publishing, pp. 95-111.

Thoyre, A. and C. Harrison (2016), 'Introduction: teaching energy geographies', Journal of Geography in Higher Education, 40, 31-8.

Upchurch, C., M. Kuby and S. Lim (2009), 'A model for the location of capacitated alternative-fuel stations', Geographical Analysis, 41, 85-106.

Zimmerer, K. (2010), 'Retrospective on nature-society geography: tracing trajectories (1911-2010) and reflecting on translations', Annals of the Association of American Geographers, 100, 1076-94. 